\title{
GROWTH OF ELECTORAL FRAUD IN NON-DEMOCRACIES: THE ROLE OF UNCERTAINTY
}

Dmitriy Vorobyev

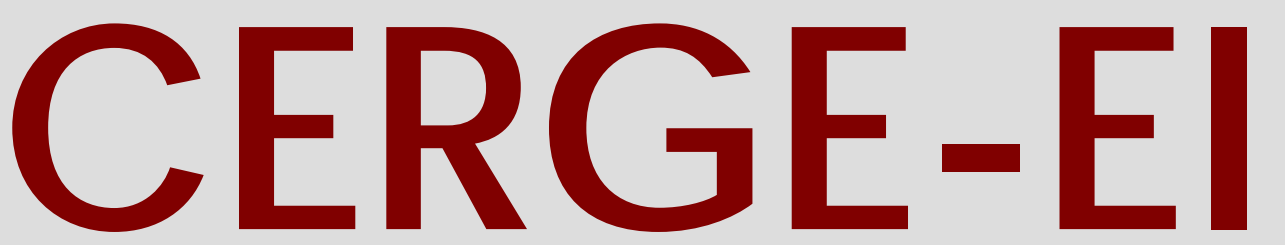

Charles University Centerfor Economic Research and Graduate Education Academy of Sciences of the Czech Republic Ec onomic s Institute 


\title{
Working Paper Series (ISSN 1211-3298)
}

\section{Growth of Electoral Fraud in Non-Democracies: The Role of Uncertainty}

Dmitriy Vorobyev

\author{
CERGE-EI \\ Prague, October 2010
}
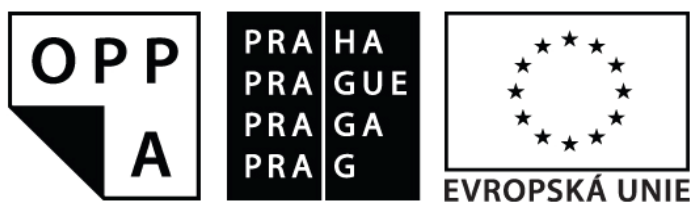

EVROPSKÝ SOCIÁLNÍ FOND

PRAHA \& EU: INVESTUJEME DO VAŠÍ BUDOUCNOSTI

Projekt je financován Evropským sociálním fondem, rozpočtem hl. města Prahy a státním rozpočtem 
ISBN 978-80-7343-218-8 (Univerzita Karlova. Centrum pro ekonomický výzkum a doktorské studium)

ISBN 978-80-7344-208-8 (Národohospodářský ústav AV ČR, v.v.i.) 


\title{
Growth of Electoral Fraud in Non-Democracies: The Role of Uncertainty*
}

\author{
Dmitriy Vorobyev ${ }^{\dagger}$
}

\begin{abstract}
Electoral fraud has become an integral part of electoral competition both in established democracies and less-than-democratic regimes. In this paper I study electoral fraud in the non-democratic setting. First, I present evidence of fraud sustainability and growth over the lifetime of non-democratic regimes in post-Soviet and Sub-Saharan countries. Second, I provide a theoretical model that explains the observed tendency of growing fraud. Specifically, in a probabilistic voting model of electoral competition with falsifications, a corrupt incumbent faces two types of uncertainty: uncertainty about voters' attitude towards fraud and uncertainty about his true support, captured by a purely random component in the voters' utility over candidates. The model predicts that when uncertainty is sufficiently large, higher uncertainty about voters' fraud intolerance provides weaker incentives to commit fraud. Over time the incumbent becomes more certain about voters' reaction to fraud because of learning through Bayesian updating and, thus, as the deterrent role of fraud intolerance uncertainty declines, the incentives to commit fraud become stronger, providing a growing fraud profile.
\end{abstract}

\begin{abstract}
Abstrakt
Volební podvody se staly nedílnou součástí volebního boje v tradičních demokraciích stejně jako v méně demokratických režimech. V tomto článku studuji volební podvody v nedemokratických uspořádáních. Nejprve prezentuji důkazy o přetrvávající existenci podvodů a jejich růst v nedemokratických režimech post-sovětského bloku a sub-saharské Afriky. Dále pak předkládám teorii, která vysvětluje pozorované tendence. Konkrétně použivám pravděpodobnostní volební model volební soutěže s podvody, kde zkorumpovaný držitel úřadu čelí dvěma druhům nejistot: nejistotě ohledně vztahu voličů k podvodům a nejistotě o skutečné podpoře, zachycené čistě náhodnou komponentou ve voličově užitkové funkci o kandidátech. Model předpovídá, že když je nejistota dostatečně velká, pak vyšší nejistota o voličově netoleranci $\mathrm{k}$ podvodům poskytuje slabší podněty ke spáchání samotného podvodu. V čase se pak držitel úřadu stává díky Bayesovskému učení více a více jistým o reakci voličů na podvod, a tudíž odstrašující role nejistoty nad reakcí na podvod klesá, motivace $\mathrm{k}$ páchání podvodů se zvětšuje a tím se vyvětluje celkový nárůst podvodů.
\end{abstract}

Keywords: Election, Voting, Fraud, Learning

JEL Classification: D72, D73, D83

\footnotetext{
* I am grateful to Libor Dušek for supervising this project as well as to Levent Celik and Peter Katuščák for helpful comments and advice. This study was supported by the World Bank Research Fellowship Grant.

${ }^{\dagger}$ Center for Economic Research and Graduate Education - Economic Institute, a joint workplace of Charles University in Prague and the Academy of Science of the Czech Republic.

Address: CERGE-EI, P.O. Box 882, Politickych veznu 7, Prague 1, 111 21, Czech Republic.

The work was supported by the grant SVV-2010-261 801.
} 


\section{Introduction}

Fair elections are fundamental to democracy. Over the last decades researchers mainly assumed that elections are well-functioning tools for converting public preferences into social choice. However, in reality, cases of manipulating electoral outcomes are quite widespread $^{1}$ even in established democracies. In less-than-democratic regimes, strategies to shape electoral results through political pressure and especially electoral fraud $^{2}$ are an integral part of political competition. International organizations exert tremendous effort to ensure transparency in elections. However, electoral fraud in nondemocracies ${ }^{3}$ seems to be not only persistent, but expanding.

All the main findings on electoral fraud are derived from the analysis of particular elections in a given country at a given moment (Lehoucq, 2003), while the issues of fraud dynamics get limited attention in academic literature. This is surprising, because studying the evolution of fraud seems to be extremely important from many different perspectives. Comprehensively studying political regimes, designing effective electoral legislation and, especially, assessing the effectiveness of electoral monitoring are much harder to do without an understanding of fraud dynamics. To assess the effect of an electoral reform on the integrity of elections or to study the role of international monitoring in improving electoral transparency, one has to understand how the electoral

\footnotetext{
${ }^{1}$ See the "Literature Review" section for references.

${ }^{2}$ Following Lehoucq (2003), I define fraud as any illegal act committed with the intent to shape an electoral result.

${ }^{3}$ Hereafter, by "non-democracy" I mean a country, which has been widely criticized for deviating from the principles of democracy although it has formal democratic institutions such as elections. Specifically, I use this term for the countries marked as "Not Free" or "Partially Free" in the Freedom House Index of Democracy: $\underline{w w w . f r e e d o m h o u s e . o r g / t e m p l a t e . c f m ? p a g e ~}=15$.
} 
environment changes over time and what are the sources of those changes. For such purposes, studying fraud dynamics is crucial.

One reason why electoral fraud suffers from a relative lack of attention in the academic literature is the absence of a reliable measure of fraud. The inability to measure fraud in a consistent way precludes implementing reliable empirical research on fraud dynamics, which in turn discourages efforts towards a theoretical study of electoral fraud, as it is hard to test any theory in this field. As a result, a set of important questions including the question of increasing fraud as well as reasons and conditions for fraud occurrence still call for an explanation. This paper is intended to partially fill this gap by studying the role of uncertainty in fraud dynamics.

The contribution of the paper is twofold. Firstly, I discuss evidence suggesting a tendency of increasing electoral fraud in Post-Soviet and Sub-Saharan non-democratic countries. Secondly, I present a game-theoretical probabilistic voting model with fraud which rationalizes the observed tendency, suggesting evolution of uncertainty about voters' attitude towards fraud as a potential explanation for growing fraud. In particular, a model of electoral competition with falsifications explicitly distinguishes between two types of uncertainty that affect electoral outcomes: aggregate uncertainty about true support, captured by a purely random component in voters' utility over candidates, and the incumbent's uncertainty about voters' fraud intolerance, represented by his subjective beliefs about the attitude of the voters towards fraud. These two uncertainties prevent the incumbent's learning about voters' fraud tolerance immediately after the first elections, providing him with a noisy signal about voters' true attitude towards fraud, which is used for Bayesian updating of the incumbent's beliefs. The model 
predicts that when there is large initial uncertainty on the incumbent's side, uncertainty about voters' attitude towards fraud negatively affects incentives to commit fraud. Over time this uncertainty decreases because of learning and, thus, provides the incumbent with greater incentives to commit fraud.

One can doubt the significance of uncertainty in explaining increasing electoral fraud, suggesting a number of obvious reasons for the observed tendency like growing stakes of re-election and decreasing costs of fraud because of learning by doing (see for instance Simpser, 2008). However, costs and stakes determine the level of committed fraud only if there is uncertainty about the outcome of the elections. In this paper I focus on the pure effect of uncertainty and show that it can also provide incentives for increasing fraud. Furthermore, in contrast to conventional wisdom (e.g., Simpser, 2008) I demonstrate that uncertainty does not always increase the incentives to commit fraud, and the direction of the effect depends on the nature of the uncertainty.

The paper is organized as follows. In the next section I review the existing literature on the issues of electoral manipulations and, particularly, electoral fraud. I then discuss problems of measuring electoral fraud and provide some evidence from Post-Soviet and Sub-Saharan countries, suggesting that electoral fraud has been growing over time. Further, I develop a formal game-theoretic dynamic model of elections with falsifications and show how uncertainty could lead to increasing fraud. 


\section{Literature Review}

Classic theories of electoral competition suggest that candidates can influence their chances of being elected only by choosing their policies. Nevertheless, in reality elections are often associated with a variety of not always legal activities that result in redistribution of votes in favor of one or another candidate. A wide stream of both theoretical and empirical literature focuses on different strategies that incumbents can use for influencing electoral outcomes. For instance, Glaeser and Schleifer (2005) show how an incumbent can engage in redistributive politics in order to shape the electorate in his favor - the so-called Curley effect. Further, a number of studies analyze political budget cycles when incumbents increase public expenditures or change their composition towards more visible goods in pre-election periods in order to attract votes, which is empirically documented by Akhmedov and Zhuravskaya (2004), Shi and Svensson (2006) and Guo (2009), for developing countries and, for instance, by Veiga and Veiga (2007) as well as Schneider (2010) for the developed ones. Political budget cycles are also widely studied theoretically starting from Rogoff (1990) and continued by, for example, Martinez (2009) who explicitly models how politicians can change their policies to improve reputation and, thus, increase chances for re-election.

Electoral fraud could be considered as another type of outcome-influencing strategies, widespread under autocracies and dictatorships where fraud tools are easily available in comparison to pure democracies. Chaturverdi (2005) and more recently Collier and Vicente (2010) study pre-election violence as an instrument for shaping electoral results through deterring opposition supporters from voting. To determine when fraud occurs 
and what should be done to prevent it, Sutter (2003) presents a simple model of rigged elections where the society decides how closely to monitor the elections, suggesting the provision of neutral observers, strengthening the protest option when fraud is detected, and reducing costs of monitoring by, for example, subsidization, as effective fraud prevention tools. However, though all the papers have focus on shaping electoral results through electoral fraud, their purposes, ways of modeling as well as the underlying assumptions do not allow for using them as a framework for studying fraud dynamics.

Simpser (2005) makes an exceptional attempt to study electoral fraud in a dynamic setting. He points out that rigged elections are often associated with very high victory margins implying that incumbents often irrationally commit excessive fraud. The author attempts to rationalize such behavior by formalizing the idea that excessive fraud can, first, deter future opposition coordination and turnout and, second, directly influence the beliefs of opposition supporters that elections will be corrupt and thus prevent their turnout. In a later paper, Simpser (2008) elaborates on this idea and comes up with a model that generates equilibrium with persistent but not growing excessive fraud. Also, the author briefly discusses the potential role of exogenous uncertainty, costs and stakes in his explanation of excessive fraud but concludes that these features cannot sufficiently explain the high victory margins observed in the data. However, the equilibrium outcome and the latter conclusion come from strict underlying assumptions, particularly, the assumption that opposition supporters, in the case of the incumbent's victory, get more utility when they abstain from voting than when they do vote (i.e. opposition supporters but not incumbent's supporters are discouraged from participating in the elections if the incumbent is very likely to win, which is a disputable assumption). 
To summarize, the existing literature on electoral fraud cannot satisfactorily explain the observed patterns in the behavior of corrupt incumbents in non-democracies that I have documented in the next section. In particular, questions of sustainability and growth of electoral fraud over non-democratic regimes' lifetimes as well as reasons and conditions for fraud occurrence still call for an explanation. This paper presents a model that tries to partially fill the gap, theoretically studying how uncertainty can affect incentives to commit fraud in non-democratic setting and how it can contribute to explaining the increasing fraud profile.

\section{Dynamics of Electoral Fraud in Non-Democracies}

For the analysis of electoral fraud dynamics, two sets of countries with non-democratic regimes are used. When refer to a "regime" I mean a period in a country's history when there was either a single leader or several leaders from the same party or family whose ruling methods are considered to be less than democratic. Specifically, I focus on regimes that existed between 1990 and 2010, that have formal democratic institutions like direct presidential elections, and that were rated as "Not Free" or "Partially Free" in the Freedom House Democracy Index (FHDI) ${ }^{4}$ for at least 2 years within their lifetimes.

The first country set consists of the Post-Soviet countries excluding Lithuania, Latvia and Estonia - democracies that entered the EU in 2003 - and Moldova, where there has been no clear regime since independence and, moreover, there have been no direct presidential elections since 1996. Finally, Turkmenistan was excluded from the set as a

\footnotetext{
${ }^{4}$ www.freedomhouse.org/template.cfm?page $=15$
} 
country without direct presidential elections throughout its whole history. In the end, the first set of countries includes Armenia, Azerbaijan, Belarus, Georgia, Kazakhstan, Kyrgyzstan, Russia, Tajikistan, Ukraine and Uzbekistan.

The second set consists of Sub-Saharan African countries that adopted elections in the early 1990s. From the total of 48 countries of the region, 7 were excluded as fully free and democratic countries (i.e., rated as "Free" in FHDI in 1991-2009 with the exception of, at most, 1 year: Benin, Botswana, Cape Verde, Mali, Namibia, Sao Tome and Principe and South Africa). An additional 7 were excluded due to too few multiparty elections (less than two or with a gap of more than 10 years) since 1990 (Angola, Burundi, DR Congo, Eritrea, Liberia, Rwanda and Sudan). Five more were excluded that did not elect presidents by direct population vote (Ethiopia, Lesotho, Mauritius, Somalia and Swaziland), and finally, 3 more countries were excluded that have not had a clear regime that has survived for at least two terms between 1990 and 2010 (Comoros, Guinea-Bissau and Sierra-Leone). Finally, the set contains 27 Sub-Saharan countries, among which one (Senegal) is represented by two consecutive distinct regimes. Information on the regimes, including dates, leaders and presidential elections years, is summarized in Table 1 of Appendix A.

To credibly analyze the evolution of electoral fraud, one needs to have some objective measure of fraud. Lehoucq (2003) suggests several types of sources that can provide valuable information for building such a measure: press, opposition parties' archives with official acquisitions on fraud, complaints submitted to courts, scientific surveys and interviews with voters, and results of international electoral monitoring. However, all of these sources, except probably the last one, could be biased towards one or 
another candidate, and, thus, cannot provide fully objective information about fraud. In addition to the fact that comprehensive analysis of such data and collecting relevant information require tremendous effort, the partisan nature of the sources limits their usefulness in measuring fraud. Results of monitoring by electoral observation missions are also limited in their ability to provide useful information on dynamics of electoral misconduct: public reports mainly contain qualitative rather than quantitative information; monitoring techniques change over time; and the objectivity of the conclusions are often questionable.

Given that electoral fraud is a phenomenon which is hard to measure directly, the only way to assess fraud dynamics is to explore some indirect evidence. Academic literature would be an ideal source of such evidence. Though empirical literature on electoral fraud dynamics is limited, there are a few papers that try to compare irregularities in consecutive elections in selected countries.

Myagkov and Ordeshook (2008) suggest a statistical methodology, based on the analysis of the distribution of turnouts over different regions, and apply it to the official data for Russian federal elections between 1993 and 2007 to uncover electoral fraud. They find that ballot stuffing and some other forms of fraud in the mid-1990s were mentioned only in a few ethnic Russian regions but then spread to the other regions, both urban and rural, with noticeable acceleration during Putin's administration (20002008). The authors stress that once fraud occurs it becomes sustainable: they find that if fraud infected a precinct in Moscow for the first time in 2004 presidential elections, it is very likely to reoccur there in the 2007 parliamentary elections. An important finding of 
the paper is that the level of electoral fraud in Russian federal elections has been both sustainable and growing with the maturing of Putin's regime.

Increasing fraud dynamics in Russia after 2000 is also discussed by Treisman (2009) who comprehensively reviews the trends in voting in Russia since 1991. In a chapter devoted to electoral manipulations and fraud, by studying a variety of Russian electoral statistics the author finds that in the early 1990s the elections in Russia were almost clean, while since 2000 the electoral irregularities have become an integral part of electoral competition. Though manipulations were not serious enough to alter the outcomes, the fraud growth was noticeable. These finding are also supported by Mebane and Kalinin (2009), who explore data on Russian federal elections for 20032008, looking for deviations from Benford's $\mathrm{Law}^{5}$ as well as other statistical anomalies that are likely to arise due to fraud. The results show unambiguously growth in electoral fraud in the 2000s: "anomalies the methods detect are worse by the end of the period under study than at the beginning"

Using a methodology similar to Myagkov and Ordeshook (2008) and Mebane and Kalinin (2009), Levin et al (2009) analyze electoral data in Venezuela and find weak evidence of increasing fraud over time. They analyze the data on two consecutive statelevel referenda in 2007 and 2009 and, assuming constant voters' preferences, discover unusual patterns in voting behavior of selected regions that mainly benefit the incumbent. Specifically, the main finding of the paper is that most of the new votes in favor of Chavez in the 2009 referendum came from the regions with large abstention in

\footnotetext{
${ }^{5}$ The Benford's Law states that in large lists of real-life data, digits are distributed in a specific, nonuniform way.

${ }^{6}$ Mebane and Kalinin (2009), page 11.
} 
2007. Though this result cannot serve as strong evidence of fraud, it is more likely to be observed if fraud had really expanded between 2007 and 2009 .

The main advantage of the discussed methodology is that it allows for the detection of electoral fraud based just on official election data. However, two main problems have to be mentioned. First, it is difficult (even impossible for the majority of African elections in the 1990s) to obtain such detailed data for all elections of interest. Second, electoral fraud is a comprehensive process (Carothers, 1997), while the method detects mainly ballot stuffing and, thus, may underestimate the magnitude of fraud. Thus, one needs to adjust the evaluation of "technical" fraud by some measure of pre-election activity that directly affects election results. The main part of such activity consists of, for instance, controlling the media and pressuring the opposition (Schedler, 2002, Enikopolov et al, 2009). Hence, indexes of media and political freedom could be used as a proxy for preelection manipulations.

First, I look at the dynamics of the Freedom House's Media Freedom Index ${ }^{7}$ for 1994 2009 for the countries of interest starting from 1994 or the year of the first multiparty elections in a country, whichever number is higher. The results are summarized in Figures 1-5 of Appendix A (higher index values correspond to lower press freedom). Generally, the figure shows that over time politicians in the countries of interest put more pressure on media: 8 post-Soviet countries out of 10 demonstrate a statistically significant positive time trend. The only outliers are Georgia and Tajikistan. In 15 out of 27 African countries, press freedom has significantly declined over time, 8 countries demonstrate no significant changes, and only 4 show clear improvement.

\footnotetext{
${ }^{7}$ www.freedomhouse.org/template.cfm?page $=16$
} 
Further, political freedom could also signal fraud-related pre-election activity, reflecting the transparency of the political environment in a given country. The evolution of political freedom in the countries of interest, captured by the popular Freedom House Political Rights Index ${ }^{8}$, shows a picture similar to the case of press freedom. Of the Post-Soviet countries, 7 out of 10 demonstrate significant growth of the index over time, which corresponds to a decrease in political freedom, 2 have no significant changes and in just 1 (Tajikistan) there is an improvement in political freedom overtime. In Africa, for 11 countries the index grows significantly, for another 11 the trend is not clear, and only 5 show improving political freedom.

The World Bank Database of Political Institutions (Beck et al, 2001) is a popular regularly updated ${ }^{9}$ source of data (1975-2009) on political systems and elections around the world. The database contains a dummy variable "fraud" that captures extraconstitutional electoral irregularities and equals to 0 only if elections are considered to be fair and 1 otherwise. Though the variable is just a dummy that does not allow for measuring the magnitude of fraud, and there are some questions how the variable is constructed (for instance, all the Russian and Zimbabwean elections before 2006 are marked as not fraudulent), one can get some inference about the time trends in electoral fraud by looking for a switch from not fraudulent elections to rigged ones within a regime's lifetime. Out of 37 countries from both sets, a switch is observed for 16: in 12 countries there is a switch from "not fraudulent" to "fraudulent", and only in 4 - vice versa.

\footnotetext{
${ }^{8}$ www.freedomhouse.org/template.cfm?page $=15$

${ }^{9}$ Last update of the DPI: April 2010
} 
Further, evolution of the victory margin ${ }^{10}$ could also provide some information about fraud given that fraudulent elections are strongly associated with high victory margins (Simpser, 2005, 2008). Victory margins in the elections of interest are summarized in Table 2 and Table 3 of Appendix A. Out of 37 countries, 21 demonstrate clear growth in the victory margin over time, 9 countries have no clear trend, and in only 7 it declines over time.

To summarize, electoral fraud is a difficult-to-measure phenomenon, and there is no objective measure that reliably reflects the magnitude of electoral misconduct. Yet, there is some indirect evidence and measures of fraud-related phenomena that can give an inference on the evolution of electoral fraud over time. The analysis of such indirect evidence in non-democratic regimes in Africa and in Post-Soviet countries suggests that electoral fraud tends to grow over time. The following section presents a formal model of fraudulent elections to show how uncertainty can contribute to the observed trends.

\section{The Model}

\section{General Setup}

This section develops a game-theoretical model of political competition between a corrupt incumbent and a challenger. The incumbent faces a continuum of voters of measure one. Before the elections, the incumbent chooses the level of fraud. The

\footnotetext{
${ }^{10}$ The victory margin is the difference between the shares of votes cast for the winner and the first runnerup
} 
incumbent derives utility only from remaining in office and thus, from his point of view, fraud is just an instrument to manipulate the probability of being re-elected. This eliminates the potential commitment problem typical for non-democracies (Acemoglu and Robinson (2006), Chapter 5) because the incumbent has no incentive to change his "policy" before the next election campaign as fraud doesn't affect the incumbent's utility. The level of chosen fraud corresponds to a unique number $f \in[0,1]$ - the share of votes that the incumbent can add to his true support. Hereafter, without loss of generality, I assume that the amount of fraud in the model equals the increment in percentage votes.

All the voters dislike fraud in the same way. Voter $i$ has utility from fraud $f$,

$$
V_{i}(f)=-\beta f
$$

where $\beta \in[0,1]$ is an "intolerance" parameter that captures voters' attitude towards fraud. Parameter $\beta$ has a true value, which is, however, unknown to the incumbent. Yet, the incumbent has prior beliefs about its value: $\beta \sim N\left(\beta_{0}, \varepsilon^{2}\right)$. Thus, the intolerancs parameter $\beta$ is subject to uncertainty, which I refer to as "fraud intolerance" uncertainty. Challenger has no opportunity to commit fraud.

The elections are modeled in a modified version of the standard probabilistic voting framework (presented for the first time in Lindbeck and Weibull (1987), later used in Persson and Tabellini (2000) and more recently in Gregory et al (2006)), where voter $i$ votes for the incumbent, who commits fraud $f$ against the challenger, if

$$
V_{i}(f)+\sigma_{i}+\delta \geq 0
$$


where $\sigma_{i}$ is an individual-specific time-constant preference over the incumbent. Across all the voters, $\sigma_{i}$, which captures a relative ideological bias towards the incumbent, is distributed uniformly over $\left[-\frac{1}{2 \varphi}, \frac{1}{2 \varphi}\right]$. The distribution is common knowledge.

Uncertainty about voters' preferences, that I hereafter call "aggregate electoral" uncertainty, is captured by $\delta$, a common for all the voters component, which represents a random preference for the incumbent shared by all voters and which is unknown to the candidates prior to election day. This component is the utility the individual derives from all the incumbent's policies other than fraud relative to all other policies of the challenger. Prior to elections the value of this component is drawn from a zero-mean normal distribution: $\delta \sim N\left(0, \psi^{2}\right)$, which is known to the incumbent.

If elected, the incumbent gets benefits from remaining in office. The benefits are normalized to 1 . The direct costs of fraud are $c(f)$ such that

$$
c(0)=0, c^{\prime}(0)=0, c^{\prime}(f) \geq 0, c^{/ /}(f) \geq 0 .
$$

Also, $c(1)$ and $c^{\prime}(1)$ are assumed to be relatively large numbers to guarantee that falsifying $100 \%$ of the votes is extremely costly.

The incumbent chooses the level of fraud to maximize his expected benefits.

The timing of the game is as follows:

1. The incumbent chooses the level of fraud $f \in[0,1]$.

2. The voters anticipate $f$, the elections take place, the results are adjusted by the level of fraud and are announced, and the winner takes office. 
3. The payoffs are realized.

Note that correct anticipation of the fraud level by voters is possible only under the assumption of no private information on the side of the incumbent. This means that to anticipate the level of fraud correctly, the voters must know preferences, costs and benefits of fraud as well as the incumbent's beliefs. If one considers this assumption to be too strict, it can be assumed that fraud is fully observable by voters. The latter assumption is not as strict as it seems from first sight because fraud, as discussed above, is a comprehensive process including controlling media and threatening the opposition that mainly takes place before elections, which is well observed by voters. With any of these two assumptions the following analysis is valid.

\section{One Period Analysis}

I start with the analysis of a one-period model. For any given level of fraud $f$, voter $i$ votes for the incumbent if

$$
\begin{gathered}
V(f)+\sigma_{i}+\delta>0, \\
-\beta f+\sigma_{i}+\delta>0, \\
\sigma_{i}>\beta f-\delta .
\end{gathered}
$$

Then, the probability that a randomly picked voter votes for the incumbent is

$$
P\left(\sigma_{i}>\beta f-\delta\right)=1-P\left(\sigma_{i} \leq \beta f-\delta\right)=1-\frac{\beta f-\delta+\frac{1}{2 \varphi}}{\frac{1}{\varphi}}=\frac{1}{2}-\varphi(\beta f-\delta)
$$


This is exactly equal to the true share of votes cast for the incumbent for a given realization of $\delta$ as there is a continuum of voters of measure 1:

$$
\pi_{I}=\frac{1}{2}-\varphi(\beta f-\delta)
$$

Note that if elections are fully free, i.e., there is no fraud, in expectation each candidate gets exactly one half of the votes.

Given the fraud level, the probability that the incumbent wins the elections under the majority rule is then

$$
P_{w}=P\left(\pi_{I}+f \geq \frac{1}{2}\right)=P\left(\frac{1}{2}-\varphi(\beta f-\delta)+f \geq \frac{1}{2}\right)=P\left(\beta-\frac{\delta}{f}-\frac{1}{\varphi} \leq 0\right) .
$$

Denote $X=\beta-\frac{\delta}{f}-\frac{1}{\varphi}$. From the incumbent's point of view $X$ is a random variable which, given his priors about $\beta$ and distribution of $\delta$, follows $N\left(\beta_{0}-\frac{1}{\varphi}, \varepsilon^{2}+\frac{\psi^{2}}{f^{2}}\right)$.

Given the expected share of votes, the incumbent chooses the level of fraud $f$ such that it maximizes his expected benefit:

$$
\max _{f} P_{w}(f)-c(f)
$$

The problem can be rewritten as:

$$
\max _{f} G_{X}(0)-c(f)
$$

where $G_{X}(z)=\frac{1}{\sqrt{2 \pi s^{2}}} \int_{-\infty}^{z} e^{-\frac{(x-\mu)^{2}}{2 s^{2}}} d x, \quad \mu=\beta_{0}-\frac{1}{\varphi}, \quad s^{2}=\varepsilon^{2}+\frac{\psi^{2}}{f^{2}}$.

The first-order condition is 


$$
-\frac{2 \psi^{2}}{f^{3}} \cdot \frac{\mu}{2 s^{2}} \cdot g_{X}(0)=c^{\prime}(f)^{11}
$$

where $g_{X}(z)=\frac{1}{\sqrt{2 \pi s^{2}}} e^{-\frac{(z-\mu)^{2}}{2 s^{2}}}$.

Proposition 1: There is unique $f^{*}$ that satisfies the first-order condition (1) if and only if $\mu=\beta_{0}-\frac{1}{\varphi}<0$. To have $f^{*} \in(0,1)$ it is sufficient to have $\quad \varepsilon^{2}+\psi^{2}>\frac{\frac{1}{\varphi}-\beta_{0}}{\sqrt{2 \pi} c /(1)}$

To understand the condition for uniqueness, recall that the incumbent's expected vote share is $E \pi_{I}=E\left(\frac{1}{2}-\varphi(\beta f-\delta)+f\right)=\frac{1}{2}+f\left(1-\varphi \beta_{0}\right)$, which is an increasing function of fraud if and only if $\varphi \beta_{0}<1$ or $\beta_{0}-\frac{1}{\varphi}<0$, otherwise committing fraud does not make sense because it hurts the incumbent in terms of votes. This can happen when people strongly dislike fraud (e.g., $\beta$ is relatively high), or when there is little heterogeneity among the electorate in terms of ideology ( $\varphi$ is high). In the latter case, by committing fraud, which is disliked by everyone, the incumbent loses a relatively large number of his ideological supporters (those with $\sigma_{i}>0$ ) as he is ideologically too close to the challenger who does not commit any fraud. Thus, the condition $\beta_{0}-\frac{1}{\varphi}<0$ guarantees that in expectation committing fraud makes sense, i.e., it provides incumbent with a higher official vote share than he would get without committing fraud.

\footnotetext{
${ }^{11}$ See the detailed derivation of the first-order condition and all the following propositions in the Appendix B.
} 
The second condition (sufficiently large uncertainty) guarantees that the left-hand side of the first-order condition (1) intersects the marginal cost function at a point between 0 and 1 . It is not binding for any reasonable parameter values mainly because marginal cost at $f=1$ is a relatively large number under the assumption that stealing $100 \%$ of the votes is extremely costly.

\section{Multi-Period Setup}

Consider a multi-period setup where we have a sequence of elections. Once the results of the first-period elections are announced, the incumbent updates his beliefs. Specifically, in the end of period 1 he observes his vote share:

$$
v_{1}=\frac{1}{2}-\varphi\left(\beta f_{1}-\delta_{1}\right)+f_{1}
$$

Because he knows the exact values of $\varphi$ and $f_{1}$, and does not know $\beta$ and $\delta_{1}$, he in fact gets an unbiased signal $m_{1}=\beta-\frac{\delta_{1}}{f_{1}}=\frac{1}{\varphi f_{1}}\left(\frac{1}{2}+f_{1}-v_{1}\right)$, which is then used for Bayesian updating of the beliefs about $\beta$.

Because $\delta$ is drawn from zero-mean normal distribution $N\left(0, \psi^{2}\right)$, signal $m$ is also distributed normally: $m_{1} \sim N\left(\beta, \frac{\psi^{2}}{f_{1}^{2}}\right)$. Given the distribution of the signal and priors $\beta \sim N\left(\beta_{0}, \varepsilon^{2}\right)$, the updated distribution of $\beta$ is

$$
\beta \mid m_{1} \sim N\left(\frac{\beta_{0} \psi^{2}+\varepsilon^{2} f_{1}^{2} m_{1}}{\psi^{2}+\varepsilon^{2} f_{1}^{2}}, \frac{\varepsilon^{2} \psi^{2}}{\psi^{2}+\varepsilon^{2} f_{1}^{2}}\right) .
$$


It is important to note that fraud in the first period affects the beliefs about $\beta$ in the second period. Specifically, the variance of the beliefs is lower if the first period fraud is higher. Also, note that if there is no fraud in the first period, the beliefs about $\beta$ do not change: when there is no fraud, there is no way to learn anything about voters' response to it.

Given the updated beliefs, in period 2 the incumbent solves

$$
\max _{f_{2}} G_{Y}(0)-c\left(f_{2}\right)
$$

where $Y=\beta-\frac{\delta_{2}}{f_{2}}-\frac{1}{\varphi}, \quad G_{Y}(z)=\frac{1}{\sqrt{2 \pi s^{2}}} \int_{-\infty}^{Z} e^{-\frac{(x-\mu)^{2}}{2 s^{2}}} d x$

$$
\mu=\frac{\beta_{0} \psi^{2}+\varepsilon^{2} f_{1}^{2} m}{\psi^{2}+\varepsilon^{2} f_{1}^{2}}-\frac{1}{\varphi}, \quad s^{2}=\frac{\varepsilon^{2} \psi^{2}}{\psi^{2}+\varepsilon^{2} f_{1}^{2}}+\frac{\psi^{2}}{f_{2}^{2}}
$$

Note that $\delta_{2}$ is again drawn from the same commonly known distribution $N\left(0, \psi^{2}\right)$ independently from the first-period draw. Later, I will explore the case when $\delta$ follows a random walk and show that the results do not substantially differ from the case with independent draws. However, random walk generates an undesirable effect (to be discussed further) that can contribute to a growing fraud profile and cannot be distinguished from the uncertainty effect. The independent draw assumption eliminates this effect, allowing us to study purely the role of uncertainty in fraud dynamics.

The second period first-order condition takes the following form:

$$
-\frac{2 \psi^{2}}{f_{2}{ }^{3}} \cdot \frac{\mu}{2 s^{2}} \cdot g_{Y}(0)-c^{\prime}\left(f_{2}\right)=0
$$

where $g_{Y}(z)=\frac{1}{\sqrt{2 \pi s^{2}}} e^{-\frac{(z-\mu)^{2}}{2 s^{2}}}$. 
To understand the conditions under which growing fraud occurs note that the only parameters of the maximization problem that are different between two periods are mean and variance of the subjective distribution of $\beta$. Recall, that from the incumbent's point of view in period one $\beta \sim N\left(\beta_{0}, \varepsilon^{2}\right)$, and in period 2, given a signal $\beta \mid m_{1} \sim N\left(\frac{\beta_{0} \psi^{2}+\varepsilon^{2} f_{1}^{* 2} m_{1}}{\psi^{2}+\varepsilon^{2} f_{1}^{* 2}}, \frac{\varepsilon^{2} \psi^{2}}{\psi^{2}+\varepsilon^{2} f_{1}^{* 2}}\right)$.

Thus, beliefs are the only thing that affects the optimal choice of fraud. For clarity, let us separate the effect of changes in beliefs on the "mean effect" and the "variance effect", i.e., changes in optimal fraud between two periods in response to changes in the mean and variance of beliefs, respectively. Further note that variance of the beliefs in the second period is always lower for any $f_{1}^{*}: \frac{\varepsilon^{2} \psi^{2}}{\psi^{2}+\varepsilon^{2} f_{1}^{* 2}}=\frac{\varepsilon^{2}}{1+\varepsilon^{2} f_{1}^{* 2} / \psi^{2}}<\varepsilon^{2}$.

The following proposition answers the question how this decrease affects the optimal level of fraud.

Proposition 2: Optimal fraud is decreasing in $\varepsilon^{2}$ if $\quad \varepsilon^{2}+\psi^{2}>\frac{\left(\frac{1}{\varphi}-\beta_{0}\right)^{2}}{3}$.

Proposition 2 says that when there is sufficiently large uncertainty (no matter of what type) an increase in fraud intolerance uncertainty leads to lower equilibrium level of fraud. Note that there are two opposite effects of uncertainty on committing fraud. On the one hand, the incumbent is afraid of committing too much fraud when he has doubts on how voters react to falsification as the intolerance parameter could easily appear to be high enough to make fraud hurting instead of benefiting (see Proposition 1). On the 
other hand, higher uncertainty implies that investment in fraud becomes less efficient. According to Proposition 2, when uncertainty is relatively high the first effect dominates. Finally, note that the condition is sufficient, meaning that the optimal fraud is decreasing in subjective uncertainty under even less strict circumstances.

Thus, more precise beliefs under sufficiently large uncertainty provide incentives to commit higher fraud, implying that the "variance effect" pushes the optimal fraud up. The next question is the direction of the "mean effect". To answer it one first needs to know how changes in the mean of beliefs affect the optimal fraud.

Proposition 3: Optimal fraud is decreasing in $\beta_{0}$ if $\quad \varepsilon^{2}+\psi^{2}>\left(\frac{1}{\varphi}-\beta_{0}\right)^{2}$.

This result, when optimal fraud is not always decreasing in the expected voter's intolerance, could seem counterintuitive. To understand it note that higher fraud intolerance should decrease incentives to commit fraud because with higher value of $\beta_{0}$, keeping the variance $\varepsilon^{2}$ fixed, the probability that true $\beta$ will appear to be high enough to make fraud electorally detrimental to the incumbent instead of beneficial (see Proposition 1) is now higher. But according to Proposition 2, increased uncertainty about fraud intolerance decreases incentives to commit fraud only when the uncertainty is sufficiently high. Thus, an increase in $\beta_{0}$ induces lower fraud only when uncertainty is relatively high. 
The second period mean $\frac{\beta_{0} \psi^{2}+\varepsilon^{2} f_{1}^{* 2} m_{1}}{\psi^{2}+\varepsilon^{2} f_{1}^{* 2}}$ is higher than $\beta_{0}$ if $m_{1}>\beta_{0}$, and $\frac{\beta_{0} \psi^{2}+\varepsilon^{2} f_{1}^{* 2} m_{1}}{\psi^{2}+\varepsilon^{2} f_{1}^{* 2}}<$ $\beta_{0}$ if $m_{1}<\beta_{0}$. Thus, according to Proposition 3, if $m_{1}<\beta_{0}$ (i.e. $\frac{\beta_{0} \psi^{2}+\varepsilon^{2} f_{1}^{* 2} m_{1}}{\psi^{2}+\varepsilon^{2} f_{1}^{* 2}}<\beta_{0}$ ) and $\varepsilon^{2}$ is high enough, the "mean" effect pushes the optimal level of fraud up as well as the "variance" effect, resulting in unambiguously increasing fraud over two periods. If $m_{1}>\beta_{0}$, the updated mean is higher than the prior mean $\left(\frac{\beta_{0} \psi^{2}+\varepsilon^{2} f_{1}^{* 2} m_{1}}{\psi^{2}+\varepsilon^{2} f_{1}^{* 2}}<\beta_{0}\right)$. In this case the "mean" and the "variance" effects influence optimal fraud in opposite ways, and the resulting direction depends on the values of the model parameters and the realized value of the signal. Specifically, the higher the signal, the more likely the "mean" effect dominates the "variance" effect, implying a decrease in fraud. Thus, there is a threshold value for signal $m^{*}{ }_{1}$ such that if $m_{1}>m^{*}{ }_{1}$ then the second period optimal fraud is lower than the first one; if $m_{1} \leq m^{*}{ }_{1}$ then the optimal fraud increases between the two periods and $m^{*}{ }_{1}>\beta_{0}$.

Because $m_{1}$ is distributed symmetrically around the true $\beta$, realization of the signal is more likely to be below the threshold value $m^{*}{ }_{1}$ implying that it is more likely to observe increasing fraud rather than decreasing, if prior beliefs are unbiased $\left(\beta_{0}=\beta\right)$. The likelihood increases if the incumbent overestimates $\beta\left(\beta_{0}>\beta\right)$.

The analysis could be easily extended to the case of a multiple period game under the assumption of a myopic incumbent. Here, myopia means that the incumbent does not invest in learning by strategic committing excessive fraud. Fully rational incumbent could have incentives to choose relatively more fraud in the first period bearing some extra risk and extra costs in exchange for faster learning the true value of $\beta$. However, 
the assumption of a fully rational incumbent seems exaggerated, taking into account some features of the real-life electoral environment, where, for example, the length of electoral cycles is rarely less than 4-6 years, which is probably too long to assume strategic fraud commitment.

The crucial thing for the results of the multi period analysis is the conditions stated in Propositions 2 and 3. The analysis is indeed valid only if the conditions hold over time. Note that both conditions require $\varepsilon^{2}$ and $\psi^{2}$ to be sufficiently large, $\varepsilon^{2}$ is decreasing over time due to learning and $\psi^{2}$ is constant over time. Thus, eventually the conditions break down. However, the higher $\psi^{2}$ and the initial value of $\varepsilon^{2}$, the later the break occurs, allowing the analysis to be valid for sufficiently large number of periods.

The following section presents the results of the simulation of the multi-period model.

\section{Simulation of the Multi-Period Model}

The multi-period setup assumes $T$ periods. At the beginning of a period $t$ the incumbent solves

$$
\max _{f_{t}} G_{H}(0)-c\left(f_{t}\right)
$$

where

$$
H=\beta-\frac{\delta_{t}}{f_{t}}-\frac{1}{\varphi}, \quad G_{H}(z)=\frac{1}{\sqrt{2 \pi s^{2}}} \int_{-\infty}^{z} e^{-\frac{(x-\mu)}{2 s^{2}}} d x
$$

$\mu=\mu_{t}\left(m_{t-1}, f_{t-1}\right)-\frac{1}{\varphi}, s^{2}=s_{t}^{2}\left(m_{t-1}, f_{t-1}\right)+\frac{\psi^{2}}{f_{t}^{2}}, \quad \mu_{t}$ and $s_{t}^{2}$ are mean and variance of the incumbent's beliefs about $\beta$ at period $t$, which are both functions of the previous period fraud and signal. 
To analyze the dynamics of fraud I simulate the multi-period model with a sequence of 6 periods. I repeat the sequence of elections 30 times, starting from the same parameter values. In each period of a sequence I solve the incumbent's problem given a quadratic cost function, resolve uncertainty by randomly drawing a value of $\delta_{t}$ from the specified distribution, and update the incumbent's beliefs. If the incumbent has lost elections, the game is over, otherwise the next period starts.

The benchmark model parameters are as follows: $\beta=0.15, \varepsilon=0.05, \psi=0.001$, $\varphi=6$. Prior beliefs are unbiased. The choice of the parameter values is not a result of calibration due to the obvious reasons discussed above. Instead, the parameters are chosen in a way that guarantees reasonable relationships between them. First, $\beta$ and $\varphi$ are set such that committing fraud makes sense (see Proposition 1). Second, $\varepsilon$ is chosen such that it guarantees reasonable uncertainty of the value of $\beta$, allowing the incumbent to assign a relatively high probability to an outcome where the voters are fraud intolerant and high fraud becomes electorally detrimental to the incumbent (see Proposition 1). Finally, variance $\psi$ of the purely random component $\delta$ is chosen such that it is relatively lower than $\varepsilon$, guarantying that a toss of a coin does not decide too much in the model and the incumbent does not lose very often because of bad luck.

To show that the exact values of the parameters do not exclusively determine the model predictions, I simulate the model for another two parameter sets, chosen in the same way as described above, in addition to the benchmark one. As a result, the model is simulated for three distinct sets:

$(\beta, \varepsilon, \psi, \varphi)=(0.15,0.05,0.001,6),(0.5,0.4,0.01,1.5),(0.8,0.25,0.025,1)$. 
In the following figures each kinked line represents optimal fraud as a function of time.

Figure 1. Optimal fraud for different parameter sets: $(\beta, \varepsilon, \psi, \varphi)=(0.15,0.05,0.001,6)$,

$(0.5,0.4,0.01,1.5),(0.8,0.25,0.025,1)$.
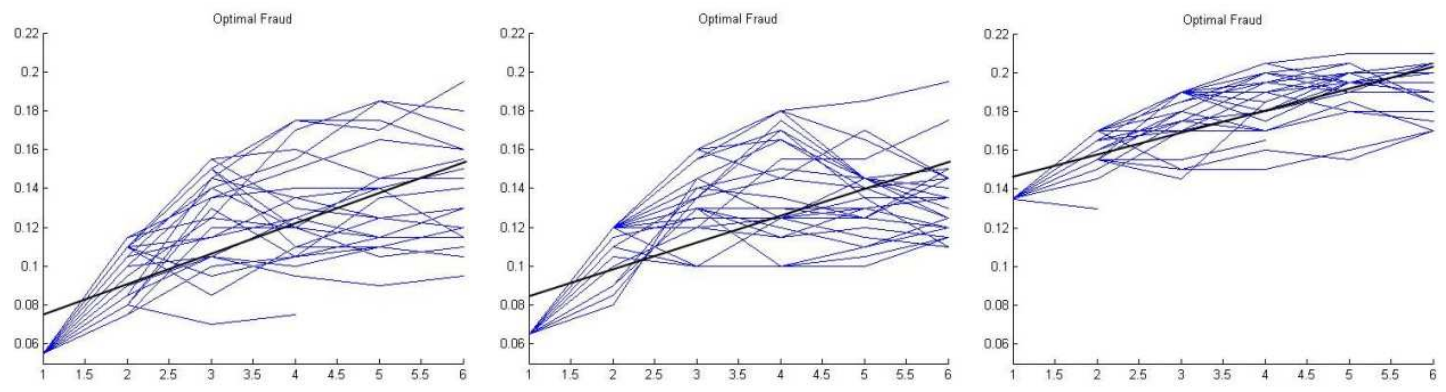

To document the significance of the growing trend I simulate the model with a sequence of 6 periods 1000 times for the parameter sets used above and run a simple regression of optimal fraud on time. The results show that in the model, fraud on average grows by about $1.1-1.5$ percentage points every period.

Table 1. Time trend of optimal fraud for the benchmark model

$\begin{array}{llll}\text { Variable } & \text { Set } 1 & \text { Set } 2 & \text { Set } 3 \\ \text { Fraud } & \text { Dependent } & \text { Dependent } & \text { Dependent } \\ \text { Time } & \begin{array}{l}0.01531 * * * \\ (0.00019)\end{array} & \begin{array}{l}0.01330 * * * \\ (0.00018)\end{array} & 0.01165 * * * \\ & & 0.00013) \\ \text { Const } & 0.06175 * * * & 0.07278 * * * & 0.13356 * * * \\ & (0.00072) & (0.00070) & (0.00049)\end{array}$

$* * * \mathrm{p}$-value $<0.0001$

One of the essential model components is the aggregate electoral uncertainty captured by parameter $\delta$. The benchmark dynamic model assumes that every period $\delta$ is independently drawn from the same normal distribution. One can argue that nonpartisan preferences over candidates could be time dependent. Finally, I allow for this 
by making $\delta$ follow a random walk instead of being independently drawn: $\delta_{t} \sim N\left(\delta_{t-1}, \psi^{2}\right)$. Again, the results of the time regressions demonstrate the significance of fraud growth.

Figure 2. Fraud in the model with random walk for different parameter sets: $(\beta, \varepsilon, \psi, \varphi)=(0.15,0.05,0.001,6),(0.5,0.4,0.01,1.5),(0.8,0.25,0.025,1)$.
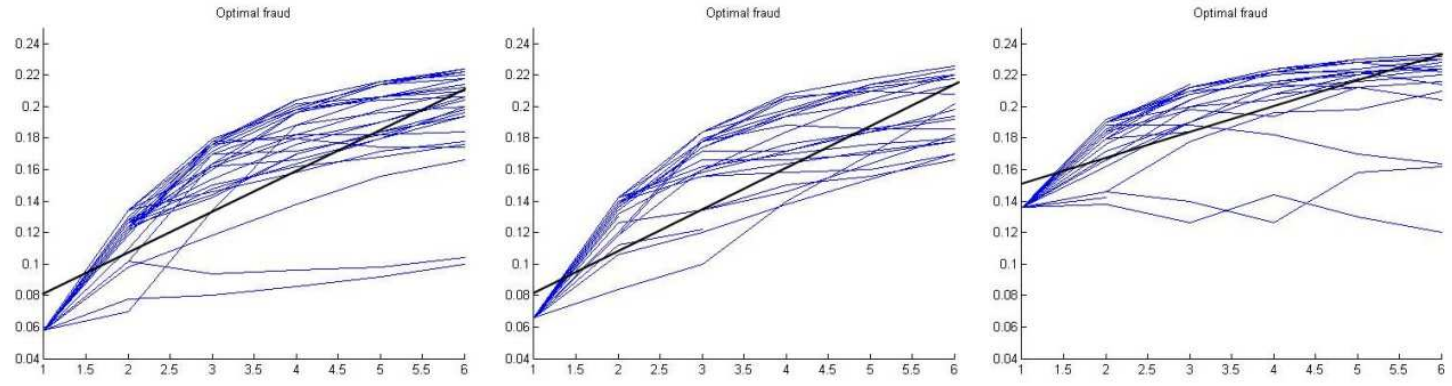

Table 2. Time trend in optimal fraud for the model with random walk

Variable

Set 1

Fraud

Time

Const

Dependent

$0.02632 * * *$

(0.00023)

$0.05486 * * *$

$(0.00085)$
Set 2

Dependent

$0.02521 * * *$

(0.00022)

$0.06517 * * *$

(0.00086)
Set 3

Dependent

$0.01611 * * *$

(0.00016)

$0.13651 * * *$

(0.00061)

$* * *$ p-value $<0.0001$

Indeed, random walk for aggregate uncertainty seems to be more realistic than independent draws. However, the growing fraud profile in this case could be a result of two effects: in addition to the effect of learning about fraud tolerance, there is also an effect of aggregate uncertainty. In contrast to the benchmark case where the aggregate uncertainty was constant over time, it is growing due to the random walk process. As a result, incentives to commit higher fraud over time are increased not only by more precise beliefs about $\beta$, but also by higher aggregate uncertainty about electoral support. Thus, for the benchmark case the assumption on independent draws for the aggregate 
uncertainty component allows for distinguishing two uncertainty time effects and, thus, seems more plausible for the purposes of the paper.

To summarize, the model simulation results in a consistent growing fraud profile which is robust to parameter choice and underlying law of motion for aggregate electoral uncertainty. When uncertainty is sufficiently large, incentives to commit fraud increase when an incumbent's uncertainty about $\beta$ decreases. Over time an incumbent's beliefs about $\beta$ becomes more precise because of learning and, thus, the deterrent role of uncertainty about fraud intolerance declines, implying that the incentives to commit fraud become stronger, leading to a growing profile.

An important observation is that fraud generally grows at a decreasing rate, which is a result of fast learning that mainly takes place in early periods. To clearly illustrate the speed of information gathering, in Figure 7, I represent the evolution of uncertainty for the three parameters sets already used above. One can notice that the standard deviation of subjective beliefs rapidly decreases in the few first periods.

Figure 3. Standard deviation of subjective beliefs for different parameter sets: $(\beta, \varepsilon, \psi, \varphi)=(0.15,0.05,0.001,6),(0.5,0.4,0.01,1.5),(0.8,0.25,0.025,1)$.
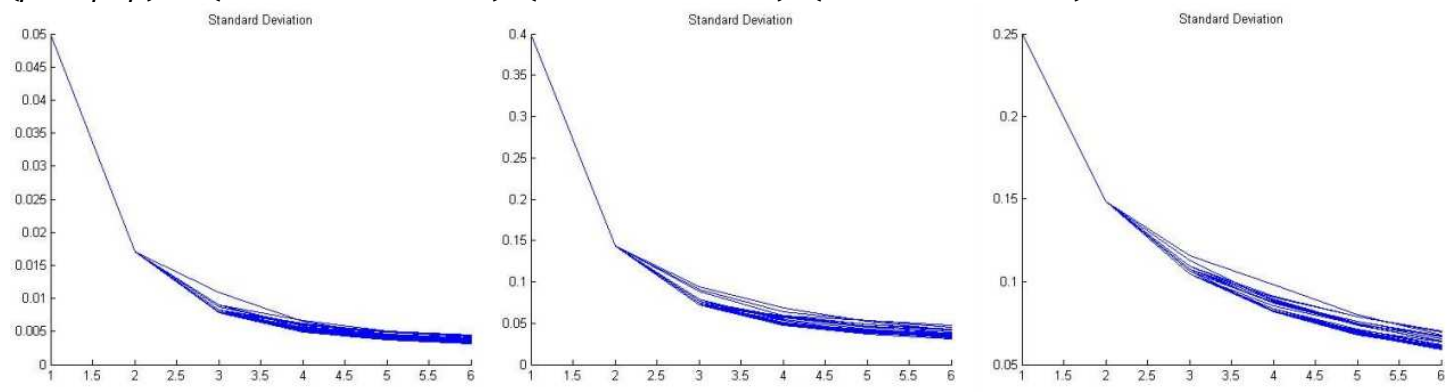

Finally, it is worth stressing that the model puts aside the effects of the growing stakes of re-election and decreasing costs of fraud because of learning-by-doing, focusing 
purely on the role of uncertainty in fraud dynamics. Obviously, being introduced into the model, these components would just magnify the results, making the model predictions even stronger.

\section{Conclusion}

This paper consists of two main parts. The first part explores different available information on electoral fraud in post-Soviet and Sub-Saharan countries. All the explored sources, including the academic literature, electoral data and data on political freedom, provide consistent, though indirect, evidence of growing fraud: electoral manipulations tend to grow over the lifetime of a non-democratic regime.

The second part provides a theoretical model of electoral competition with falsifications designed in the traditional probabilistic voting framework which specifically studies the effect of uncertainty on the incumbent's incentives to commit fraud. The model explicitly distinguishes between two types of uncertainty that affect electoral outcomes: aggregate electoral uncertainty, captured by a purely random component in voters' utility over candidates, and subjective uncertainty about voters' fraud intolerance, represented by the variance of an incumbent's beliefs about the fraud intolerance component in voters' utility. The most important findings of the model are as follows.

First, when uncertainty (no matter of what type) is sufficiently large, incentives to commit fraud increase when an incumbent's uncertainty about fraud intolerance decreases. Second, because in the multi-period setup an incumbent's uncertainty 
decreases as a result of learning through Bayesian updating, increasing fraud is more likely to be observed. Third, optimal fraud demonstrates an increasing profile at a decreasing rate. This is explained by fast learning that mainly takes place in early periods: the incumbent quickly absorbs information about the true value of the intolerance component in voters' utility function. The predictions are robust to functional forms of the model components as well as choice of parameter values. 


\section{References}

Acemoglu, D., Robinson, J., 2006. Economic Origins of Dictatorship and Democracy. New York: Cambridge University Press.

Akhmedov, A., Zhuravskaya, E., 2004. Opportunistic Political Cycles: Test in a Young Democracy Setting. The Quarterly Journal of Economics, November, Vol. 119, No. 4, 13011338.

Beck, T., Clarke, G., Groff, A., Keefer P., Walsh, P., 2001. New Tools and New Tests in Comparative Political Economy: the Database of Political Institutions. World Bank Economic Review, 15 (September), 165-176.

Carothers, T., 1997. The Observers Observed. Journal of Democracy, Vol. 8, No.3, 17-31.

Chaturvedi, A., 2005. Rigging Elections with Violence. Public Choice, 125, 189-202.

Collier, P., Vicente, P., 2010. Violence, Bribery, and Fraud: The Political Economy of Elections in Africa, Working Paper, University of Oxford.

Enikopolov, R., Petrova, M., Zhuravskaya, E., 2009. Media and Political Persuasion: Evidence from Russia. CEPR Discussion Paper, No. DP7257.

Glaeser, E.L., Schleifer, A., 2005. The Curley Effect: The Economics of Shaping the Electorate. The Journal of Law, Economics, \& Organization, Vol. 21, No. 1, 1-19.

Gregory, P., Schroder, P., Sonin, K., 2006. Dictators, Repression and the Median Citizen: An Eliminations Model of Stalin's Terror (Data from the NKVD Archives), Mimeo.

Guo, G., 2009. China's Local Political Budget Cycles. American Journal of Political Science, Vol. 53, Issue 3, 621-632.

Lehoucq, F., 2003. Electoral Fraud: Causes, Types and Consequences. Annual Review of Political Science, 6, 233-256.

Levin, I.,Cohn, G., Ordeshook, P., Alvarez, R., 2009. Detecting Voter Fraud in an Electronic Voting Context: An Analysis of the Unlimited Reelection Vote in Venezuela. Electronic Voting Technology Workshop / Workshop on Trustworthy Elections, Online Proceedings. 
Lindbeck, A., Weibull, J., 1987. Balanced-Budget Redistribution as the Outcome of Political Competition. Public Choice, 52, 273-297.

Martinez, L., 2009. A Theory of Political Cycles. Journal of Economic Theory, 144, 11661186.

Mebane W., Kalinin, K., 2009. Comparative Election Fraud Detection. Presented at the Annual Meeting of the APSA.

Myagkov, M., Ordershook, P., 2008. Russian Elections: An Oxymoron of Democracy. VTP Working Paper.

Persson T., Tabellini, G., 2000. Political Economics: Explaining Economic Policy. MIT Press.

Rogoff, K., 1990. Equilibrium Political Budget Cycles. American Economic Review, 80, 21-36.

Schedler, A., 2002. Elections without Democracy: The Menu of Manipulation. Journal of Democracy, Vol. 13, No.2, 36-50.

Schneider, C., 2010. Fighting with One Hand Tied behind the Back: Political Budget Cycles in the West German States. Public Choice, 142, 125-150.

Shi, M., Svensson, J., 2006. Political Budget Cycles: Do They Differ Across Countries and Why? Journal of Public Economics, 90, 1367-1389.

Simpser, A., 2005. Making Votes Not Count: Strategic Incentives for Electoral Corruption, PhD Dissertation, Stanford University.

Simpser, A., 2008. Cheating Big: On the Logic of Electoral Corruption in Developing Countries. Mimeo, University of Chicago.

Sutter, D., 2003. Detecting and Correcting Electoral Fraud. Eastern Economic Journal, Vol. 29, No. 3, summer, 433-451.

Treisman, D., 2009. Elections in Russia, 1991-2008. Working paper, Moscow State University - Higher School of Economics.

Veiga, L., Veiga, F., 2007. Political Business Cycles at The Municipal Level. Public Choice, $131,45-64$. 


\section{Appendix A. Electoral Data}

Table 1. Countries of Interest.

\begin{tabular}{|c|c|c|c|c|}
\hline Country & Code & Regime & Leaders & Presidential Elections \\
\hline Burkina Faso & BFA & $1987-$ & Blaise Compaore & $1991,1998,2005$ \\
\hline Cameroon & CMR & $1982-$ & Paul Biya & $1992,1997,2004$ \\
\hline CAR & CAF & $1993-2003$ & Ange-Félix Patassé & 1993,1999 \\
\hline Chad & TCD & $1990-$ & Idriss Deby & $1996,2001,2006$ \\
\hline Congo & COG & $1997-$ & Denis Sassou-Nguesso & 2002,2009 \\
\hline Cote d'Ivuare & CIV & 1960-1999 & $\begin{array}{l}\text { Félix Houphouët-Boigny, Henri } \\
\text { Konan Bédié }\end{array}$ & 1990,1995 \\
\hline Djibouty & DJI & $1977-$ & $\begin{array}{l}\text { Hassan Gouled Aptidon, Ismail } \\
\text { Omar Guelleh }\end{array}$ & $1993,1999,2005$ \\
\hline Eq. Guinea & GNQ & $1979-$ & Teodoro Obiang Nguema Mbasogo & $1996,2002,2009$ \\
\hline Gabon & GAB & $1967-$ & Omar Bongo & $1993,1998,2005$ \\
\hline Gambia & GMB & $1994-$ & Yahya Jammeh & $1996,2001,2006$ \\
\hline Ghana & GHA & $1982-2000$ & Jerry Rawlings & $1992,1996,2000$ \\
\hline Guinea & GIN & 1984-2008 & Lansana Conte & $1993,1998,2003$ \\
\hline Kenya & KEN & 1978-2002 & Daniel Moi & $1992,1997,2002$ \\
\hline Madagascar & MDG & $2001-2009$ & Marc Ravalomanana & 2001,2006 \\
\hline Malawi & MWI & $1994-$ & Baliki Muluzi, Bingu wa Mutharika & $1994,1999,2004,2009$ \\
\hline Mauritania & MRT & 1984-2005 & Maaouya Ould Sid’Ahmed Taya & $1992,1997,2003$ \\
\hline Mozambique & $\mathrm{MOZ}$ & $1986-$ & $\begin{array}{lll}\text { Joaquim } & \text { Chissano, } & \text { Armando } \\
\text { Guebuza } & & \\
\end{array}$ & $1994,1999,2004$ \\
\hline Niger & NER & 1999-2010 & Mamadou Tandja & 1999,2004 \\
\hline Nigeria & NGA & $1997-$ & $\begin{array}{lll}\text { Olusegun } & \text { Obasanjo, } & \text { Umaru } \\
\text { Yar'Adua } & & \\
\end{array}$ & $1999,2003,2007$ \\
\hline Senegal & SEN1 & $1960-2000$ & Leopold Senghor, Abdou Diouf & $\begin{array}{l}1978,1983,1988,1993, \\
2000\end{array}$ \\
\hline Senegal & SEN2 & $2000-$ & Abdoulaye Wade & 2000,2007 \\
\hline Seychelles & SYC & $1977-$ & France-Albert René, James Michel & $1993,1998,2001$ \\
\hline Tanzania & TZA & $1960-$ & $\begin{array}{l}\text { Julius Nyerere, Ali Hassan Mwinyi, } \\
\text { Benjamin Mkapa, Jakaya } \\
\text { Mrisho Kikwete }\end{array}$ & $1995,2000,2005$ \\
\hline Togo & TGO & $1993-$ & $\begin{array}{lll}\text { Gnassingbé } & \text { Eyadéma, } & \text { Faure } \\
\text { Gnassingbé }\end{array}$ & $1993,1998,2003,2005$ \\
\hline Uganda & UGA & $1986-$ & Yoweri Kaguta Museveni & $1996,2001,2006$ \\
\hline Zambia & ZMB & $1991-$ & $\begin{array}{lll}\text { Levy } \quad \text { Mwanawasa, } & \text { Frederick } \\
\text { Chiluba, Rupiah Banda } & \\
\end{array}$ & $\begin{array}{l}\text { 1991, 1996, 2001, 2006, } \\
2008\end{array}$ \\
\hline Zimbabwe & ZWE & $1987-$ & Robert Mugabe & $1990,1996,2002,2008$ \\
\hline Armenia & ARM & $1998-$ & Robert Kocharyan, Serzh Sargsyan & $1998,2003,2008$ \\
\hline Azerbaijan & AZE & 1993- & Heydar Aliyev, Ilham Aliyev & $1993,1998,2003,2008$ \\
\hline Belarus & BLR & $1994-$ & Alexander Lukashenko & $1994,2001,2006$ \\
\hline Georgia & GEO & $1995-2003$ & Eduard Shevardnadze & 1995,2000 \\
\hline Kazakhstan & KAZ & $1991-$ & Nursultan Nazarbaev & $1991,1999,2005$ \\
\hline Kyrgyzstan & KGZ & 1990-2005 & Askar Akayev & $1991,1995,2000$ \\
\hline Russia & RUS & $2000-$ & Vladimir Putin, Dmitriy Medvedev & $2000,2004,2008$ \\
\hline Tajikistan & TJK & $1992-$ & Emomali Rahmon & $1995,1999,2006$ \\
\hline Ukraine & UKR & 1994-2004 & Leonid Kuchma & 1994,1999 \\
\hline Uzbekistan & UZB & $1990-$ & Islam Karimov & $1991,2000,2007$ \\
\hline
\end{tabular}




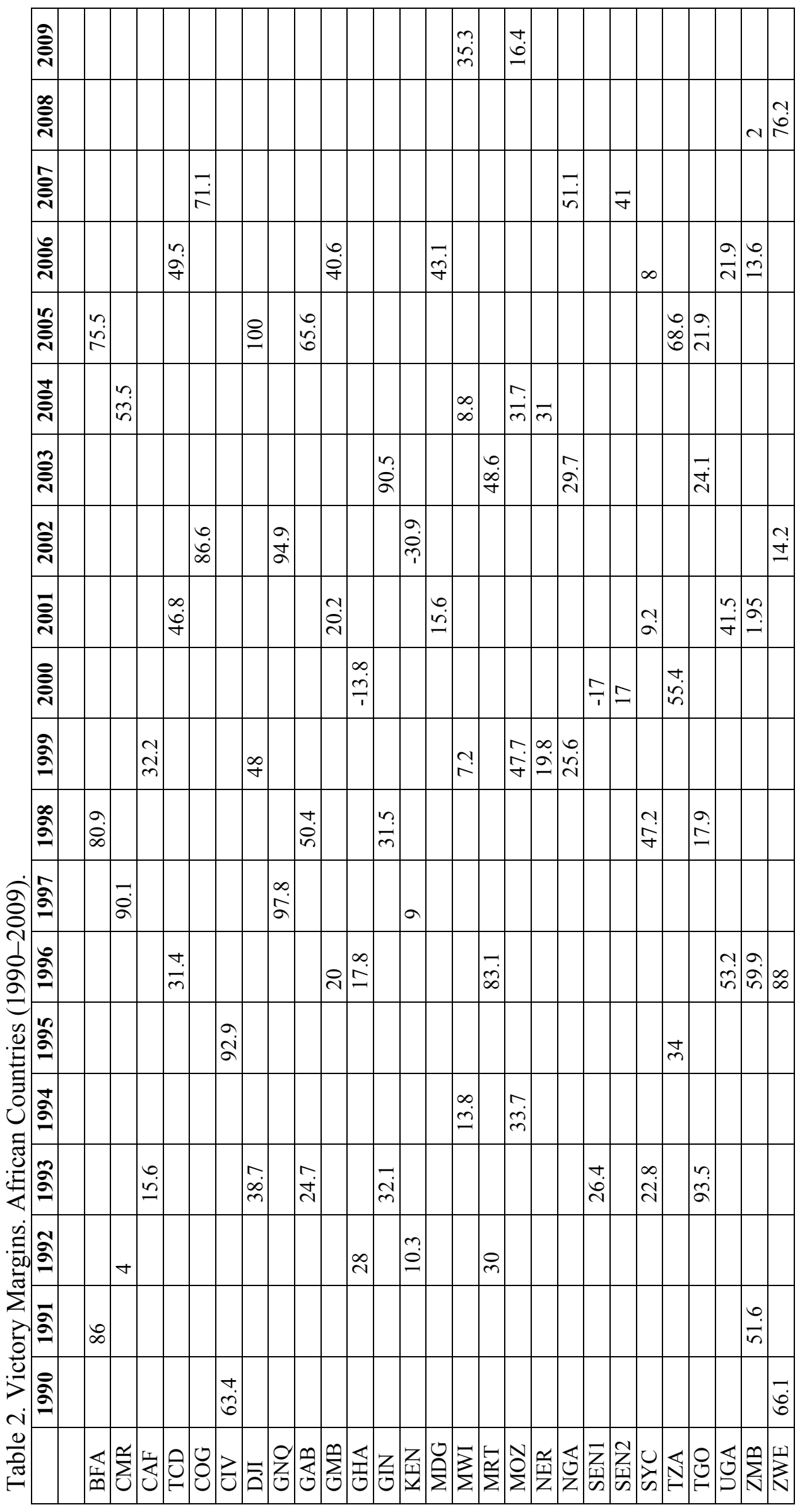




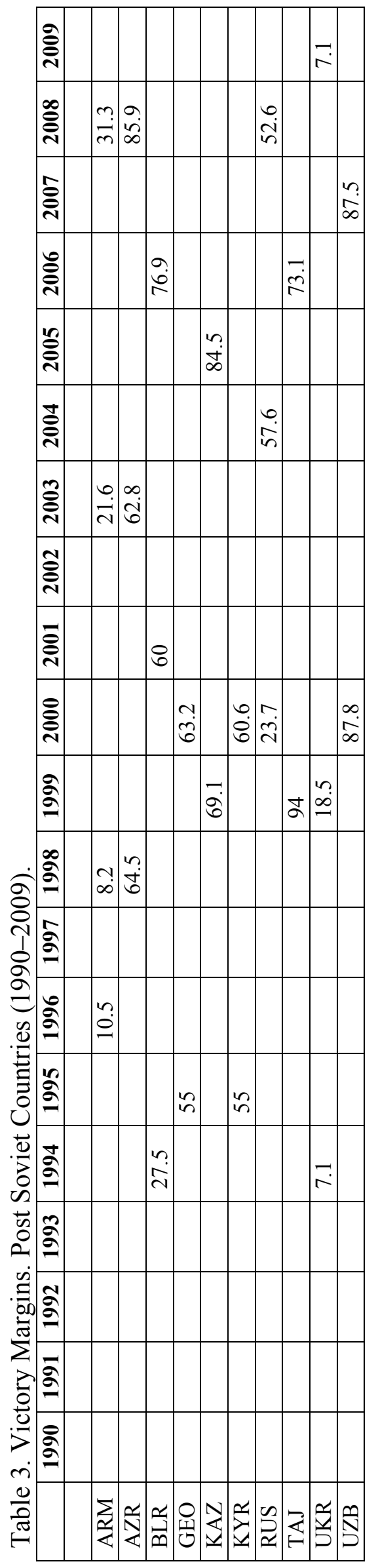


Figure 1. Evolution of Press Freedom in Post-Soviet Countries

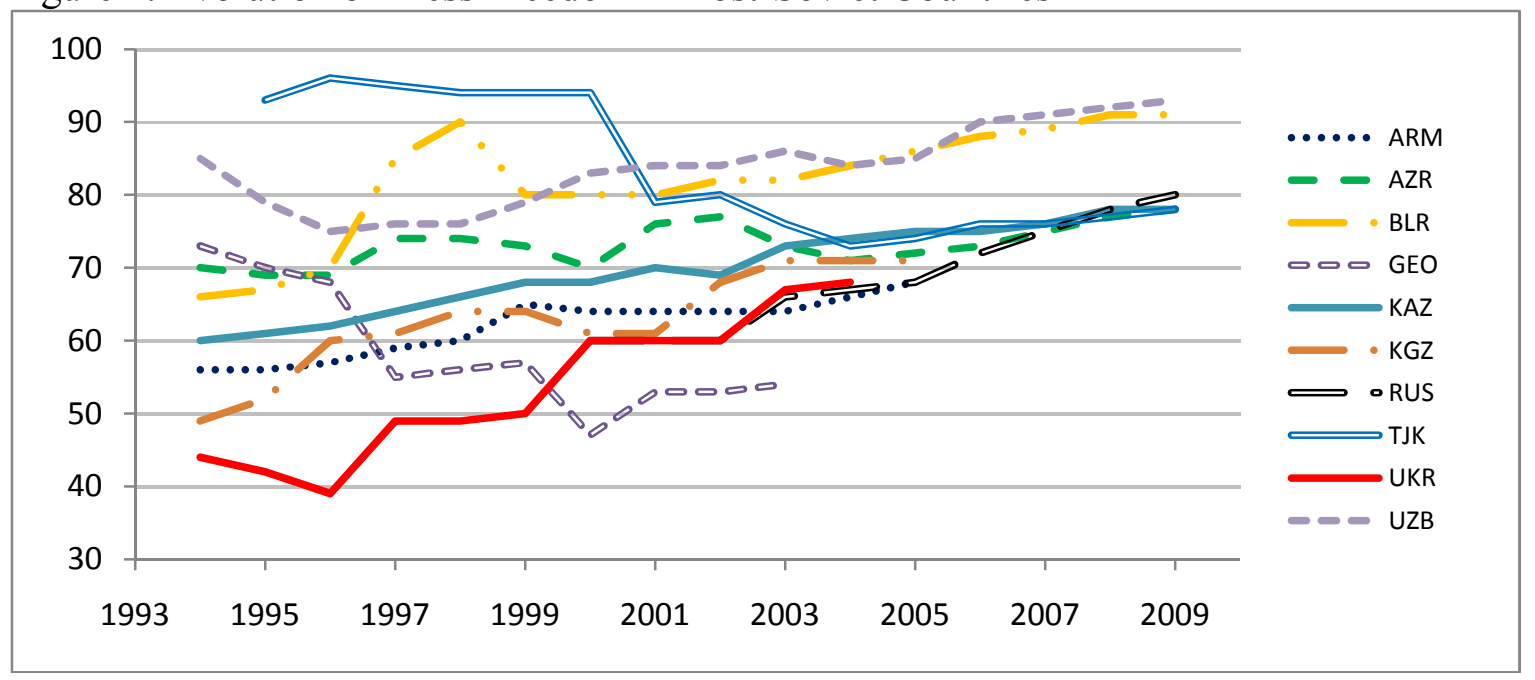

Figure 2. Evolution of Press Freedom in Sub-Saharan Countries. Part 1.

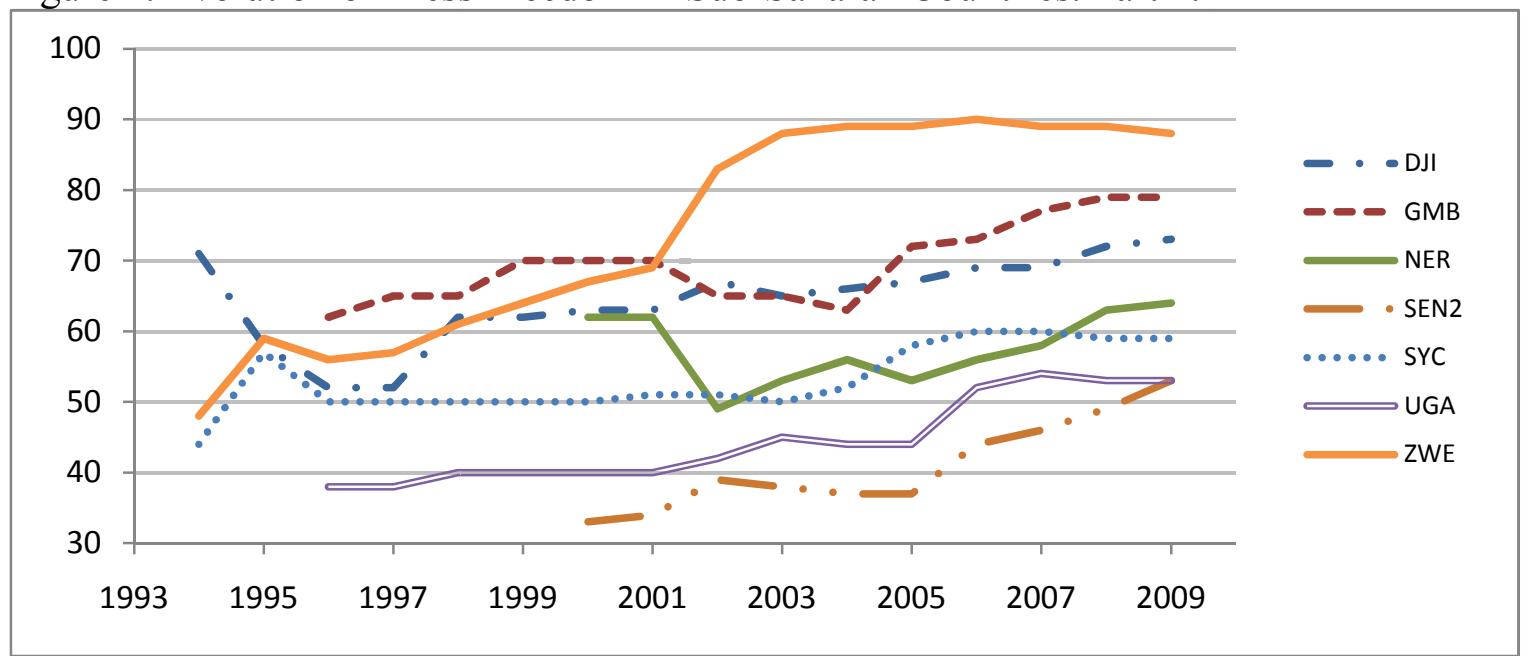

Figure 3. Evolution of Press Freedom in Sub-Saharan Countries. Part 2.

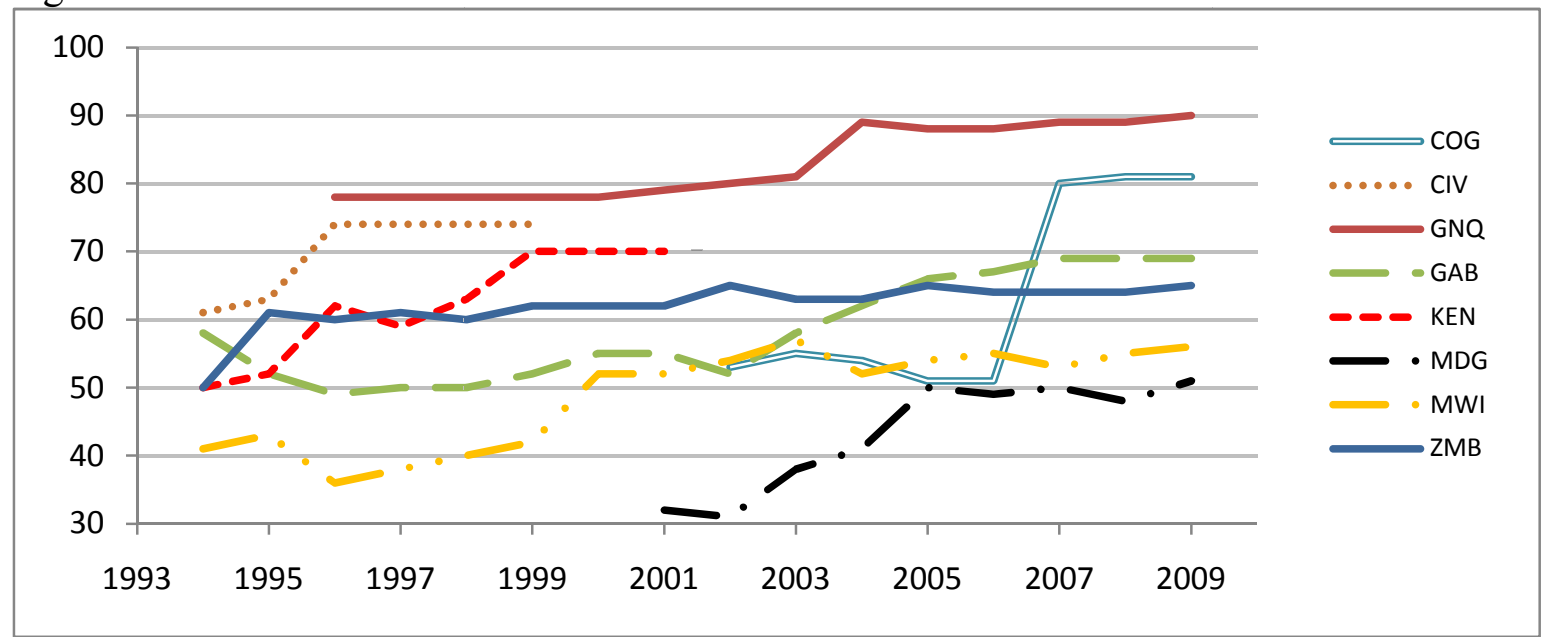


Figure 4. Evolution of Press Freedom in Sub-Saharan Countries. Part 3.

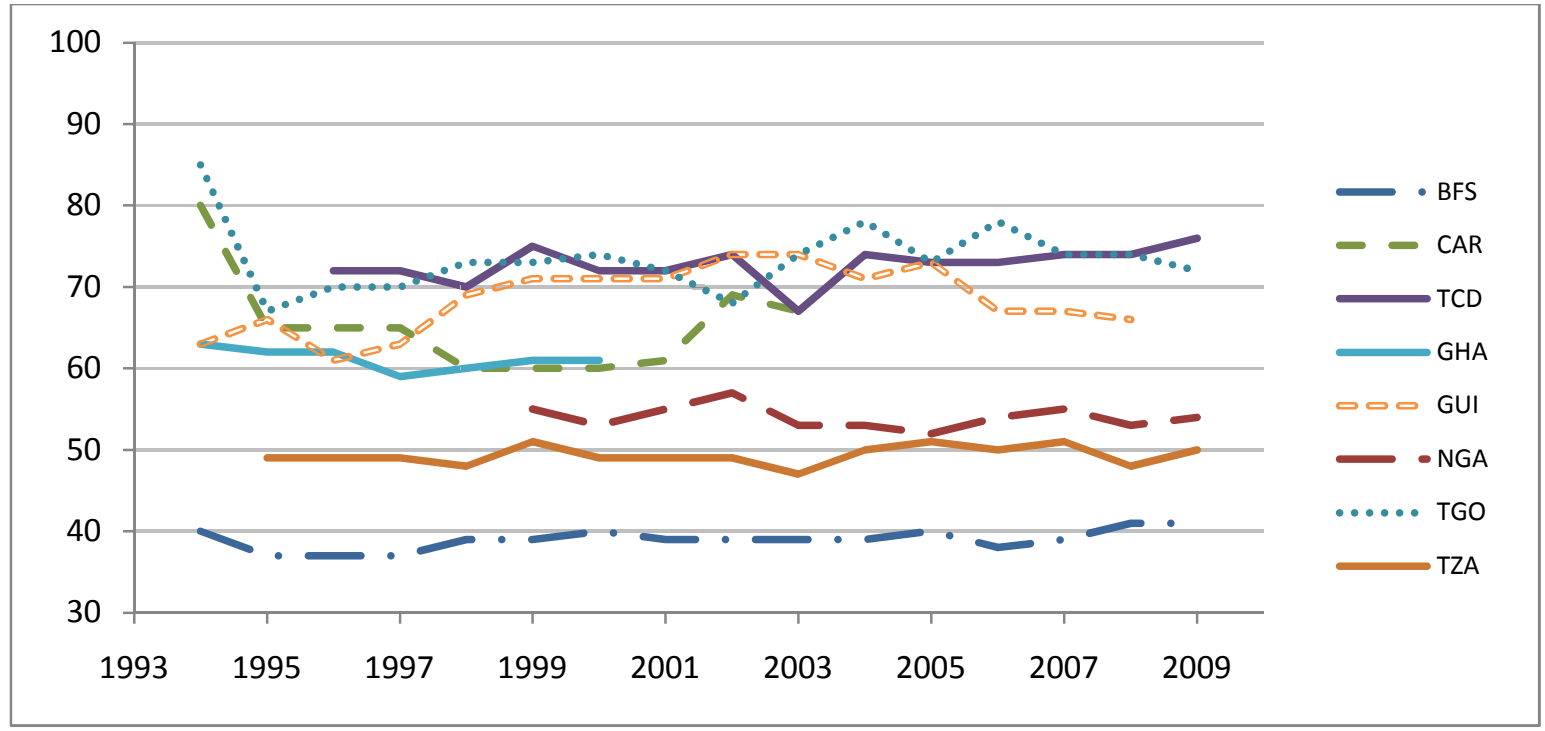

Figure 5. Evolution of Press Freedom in Sub-Saharan Countries. Part 4.

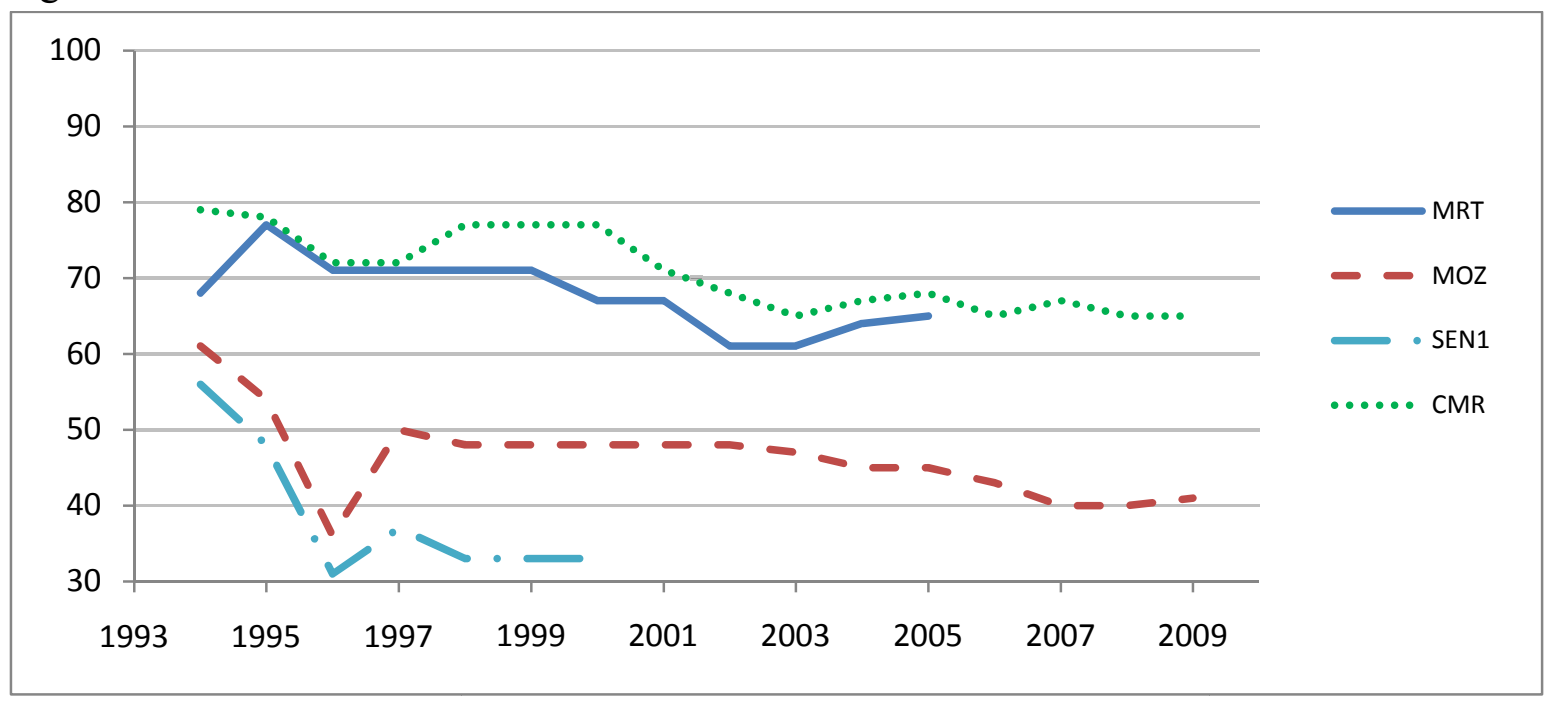




\section{Appendix B. Proofs}

First-Order Condition Derivation

$$
\max _{f} G_{X}(0)-c(f)
$$

where $G_{X}(z)=\frac{1}{\sqrt{2 \pi s^{2}}} \int_{-\infty}^{z} e^{-\frac{(x-\mu)^{2}}{2 s^{2}}} d x, \quad \mu=\beta_{0}-\frac{1}{\varphi}, \quad s^{2}=\varepsilon^{2}+\frac{\psi^{2}}{f^{2}}$.

FOC: $\frac{d G_{X}(0)}{d f}=c^{\prime}(f)$,

$\frac{d G_{X}(0)}{d f}=\frac{d G_{X}(0)}{d s^{2}} \frac{d s^{2}}{d f}=-\frac{2 \psi^{2}}{f^{3}} \frac{d G_{X}(0)}{d s^{2}}$,

$\frac{d G_{X}(0)}{d s^{2}}=-\frac{1}{2 \sqrt{2 \pi} s^{3}} \int_{-\infty}^{0} e^{-\frac{(x-\mu)^{2}}{2 s^{2}}} d x+\frac{1}{\sqrt{2 \pi s^{2}}} \int_{-\infty}^{0} \frac{d}{d s}\left(e^{-\frac{(x-\mu)^{2}}{2 s^{2}}}\right) d x=-\frac{1}{2 s^{2}} G_{X}(0)+I$

$I=\frac{1}{\sqrt{2 \pi s^{2}}} \int_{-\infty}^{0} \frac{d}{d s}\left(e^{-\frac{(x-\mu)^{2}}{2 s^{2}}}\right) d x=\frac{1}{\sqrt{2 \pi s^{2}}} \int_{-\infty}^{0} \frac{(x-\mu)^{2}}{2} \frac{1}{s^{4}} e^{-\frac{(x-\mu)^{2}}{2 s^{2}}} d x=\frac{1}{\sqrt{2 \pi s^{2}} s^{2}} \int_{-\infty}^{0} \frac{(x-\mu)^{2}}{2 s^{2}} e^{-\frac{(x-\mu)^{2}}{2 s^{2}}} d x$

Using a substitution $z=\frac{x-\mu}{\sqrt{2 s^{2}}}, \quad I=\frac{1}{\sqrt{\pi} s^{2}} \int_{-\infty}^{-\mu / \sqrt{2 s^{2}}} z^{2} e^{-z^{2}} d z$

Integrating by parts with substitution $U=z$ and $d V=z^{2} e^{-z^{2}} d z$ :

$$
\int_{-\infty}^{a} z^{2} e^{-z^{2}} d z=-\frac{1}{2} a e^{-a^{2}}+\frac{1}{2} \int_{-\infty}^{a} e^{-z^{2}} d z
$$

Applying this expression to the integral (2):

$I=\frac{1}{\sqrt{\pi} s^{2}} \int_{-\infty}^{-\mu / \sqrt{2 s^{2}}} z^{2} e^{-z^{2}} d z=\frac{1}{\sqrt{\pi} s^{2}}\left[\frac{1}{2} \frac{\mu}{\sqrt{2 s^{2}}} e^{-\frac{\mu^{2}}{2 s^{2}}}+\frac{1}{2} \int_{-\infty}^{-\mu / \sqrt{2 s^{2}}} e^{-z^{2}} d z\right]=\frac{1}{2 s^{2}}\left[\frac{\mu}{\sqrt{2 \pi s^{2}}} e^{-\frac{\mu^{2}}{2 s^{2}}}+\right.$ GXO .

$I=\frac{1}{2 s^{2}}\left[\mu g_{X}(0)+G_{X}(0)\right]$

Plugging the expression back to formula (1):

$$
\frac{d G_{X}(0)}{d s^{2}}=-\frac{1}{2 s^{2}} G_{X}(0)+I=-\frac{1}{2 s^{2}} G_{X}(0)+\frac{1}{2 s^{2}}\left[\mu g_{X}(0)+G_{X}(0)\right]=\frac{\mu}{2 s^{2}} g_{X}(0) .
$$

Finally, $\frac{d G_{X}(0)}{d f}=-\frac{2 \psi^{2}}{f^{3}} \frac{d G_{X}(0)}{d s^{2}}=-\frac{\psi^{2}}{f^{3}} \frac{\mu}{s^{2}} g_{X}(0)$. 


\section{Proof of Proposition 1}

The incumbent's expected share of votes $\pi_{I}=\frac{1}{2}+\left(1-\varphi \beta_{0}\right) f$ is decreasing in $f$ if and only if $\beta_{0}-\frac{1}{\varphi}<0$. Otherwise, it is always optimal to choose zero fraud.

The left hand side of the first-order condition $(1) L H S_{I}(f)=-\frac{2 \psi^{2}}{f^{3}} \cdot \frac{\mu}{2 s^{2}} \cdot g_{X}(0)$ is a strictly decreasing function of fraud whenever the first part of the proposition is satisfied. Because marginal cost $c^{\prime}(f)$ is a non-decreasing function of fraud, and $L H S_{I}(0)=\frac{\frac{1}{\varphi}-\beta_{0}}{\psi \sqrt{2 \pi}}>0=c^{\prime}(0)$, there is a unique intersection between $L H S_{l}(f)$ and $c^{\prime}(f)$. To show that the intersection point is between 0 and 1 , it is sufficient to show that $\operatorname{LHS}_{1}(1)<c^{\prime}(1)$ :

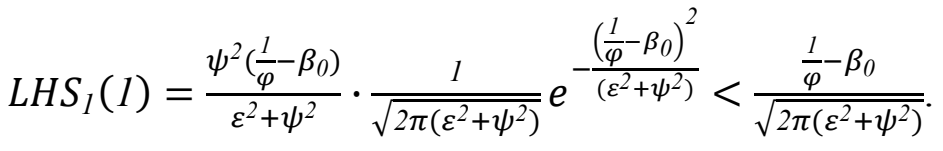

Thus, to have optimal fraud less than 1 , it is sufficient to have $\frac{\frac{1}{\varphi}-\beta_{0}}{\sqrt{2 \pi\left(\varepsilon^{2}+\psi^{2}\right)}}<c^{\prime}(1)$.

\section{Proof of Proposition 2}

Denote the first-order condition (1) as $F=-\frac{2 \psi^{2}}{f^{* 3}} \cdot \frac{\mu}{2 s^{2}} \cdot g_{X}(0)-c^{\prime}\left(f^{*}\right)$ and use the implicit function theorem: $\frac{\partial f^{*}}{\partial \varepsilon^{2}}=-\frac{\partial F / \partial \varepsilon^{2}}{\partial F / \partial f^{*}}$.

Note that because $\mu<0, \frac{\partial F}{\partial f^{*}}=\frac{\psi^{2} \mu g_{X}(0)}{\left(f^{* 2} \varepsilon^{2}+\psi^{2}\right)^{2}} \cdot\left[\frac{\psi^{2} \mu^{2}}{f^{* 2} \varepsilon^{2}+\psi^{2}}+3 \varepsilon^{2}\right]-c^{/ /}(f)<0$.

$\frac{\partial F}{\partial \varepsilon^{2}}=-\frac{\psi^{2} \mu g_{X}(0) f^{*}}{2\left(f^{* 2} \varepsilon^{2}+\psi^{2}\right)^{2}}\left[\frac{\mu^{2}}{s^{2}}-3\right]$. This expression is negative if and only if $\frac{\mu^{2}}{s^{2}}<3$.

Because $\frac{\mu^{2}}{s^{2}}=\frac{\mu^{2}}{\varepsilon^{2}+\frac{\psi^{2}}{f^{2}}}<\frac{\mu^{2}}{\varepsilon^{2}+\psi^{2}}$ to guarantee $\frac{\partial F}{\partial \varepsilon^{2}}<0$ it is sufficient to have $\frac{\mu^{2}}{\varepsilon^{2}+\psi^{2}}<3$ or $\varepsilon^{2}+\psi^{2}>$ $\frac{\mu^{2}}{3}$, which in its turn guarantees that $\frac{\partial f^{*}}{\partial \varepsilon^{2}}<0$. 
Proof of Proposition 3

$\frac{\partial f^{*}}{\partial \beta_{0}}=\frac{\partial f^{*}}{\partial \mu} \frac{\partial \mu}{\partial \beta_{0}}=\frac{\partial f^{*}}{\partial \mu}$

Similar to Propositions 2 and $3: \frac{\partial f^{*}}{\partial \mu}=-\frac{\partial F / \partial \mu}{\partial F / \partial f^{*}} ; \quad \frac{\partial F}{\partial f^{*}}=\frac{\psi^{2} \mu g_{X}(0)}{\left(f^{* 2} \varepsilon^{2}+\psi^{2}\right)^{2}} \cdot\left[\frac{\psi^{2} \mu^{2}}{f^{* 2} \varepsilon^{2}+\psi^{2}}+3 \varepsilon^{2}\right]-$ $c^{/ /}(f)<0$.

Thus to prove the proposition it is enough to show that $\frac{\partial F}{\partial \mu}<0$.

$\frac{\partial F}{\partial \mu}=-\frac{\psi g_{X}(0)}{f^{*}\left(f^{* 2} \varepsilon^{2}+\psi^{2}\right)}\left(1-\frac{\mu^{2}}{s^{2}}\right)$. To make this expression negative, it is necessary and sufficient to have $\frac{\mu^{2}}{\varepsilon^{2}+\frac{\psi^{2}}{f^{2}}}<1$, which always holds if $\frac{\mu^{2}}{\varepsilon^{2}+\psi^{2}}<1$ or $\varepsilon^{2}+\psi^{2}>\mu^{2}$. 


\section{Working Paper Series}

ISSN 1211-3298

Registration No. (Ministry of Culture): E 19443

Individual researchers, as well as the on-line and printed versions of the CERGE-EI Working Papers (including their dissemination) were supported from the European Structural Fund (within the Operational Programme Prague Adaptability), the budget of the City of Prague, the Czech Republic's state budget and the following institutional grants:

- Center of Advanced Political Economy Research [Centrum pro pokročilá politickoekonomická studia], No. LC542, (2005-2010);

- Economic Aspects of EU and EMU Entry [Ekonomické aspekty vstupu do Evropské unie a Evropské měnové unie], No. AVOZ70850503, (2005-2010);

- Economic Impact of European Integration on the Czech Republic [Ekonomické dopady evropské integrace na ČR], No. MSM0021620846, (2005-2011);

Specific research support and/or other grants the researchers/publications benefited from are acknowledged at the beginning of the Paper.

(c) Dmitriy Vorobyev, 2010

All rights reserved. No part of this publication may be reproduced, stored in a retrieval system or transmitted in any form or by any means, electronic, mechanical or photocopying, recording, or otherwise without the prior permission of the publisher.

Published by

Charles University in Prague, Center for Economic Research and Graduate Education (CERGE) and

Economics Institute ASCR, v. v. i. (EI)

CERGE-El, Politických vězňů 7, 11121 Prague 1, tel.: +420 224005 153, Czech Republic.

Printed by CERGE-EI, Prague

Subscription: CERGE-EI homepage: http://www.cerge-ei.cz

Phone: + 420224005153

Email: office@cerge-ei.cz

Web: http://www.cerge-ei.cz

Editor: Michal Kejak

Editorial board: Jan Kmenta, Randall Filer, Petr Zemčík

The paper is available online at http://www.cerge-ei.cz/publications/working_papers/.

ISBN 978-80-7343-218-8 (Univerzita Karlova. Centrum pro ekonomický výzkum a doktorské studium)

ISBN 978-80-7344-208-8 (Národohospodářský ústav AV ČR, v. v. i.) 
CERGE-EI

P.O.BOX 882

Politických vězňů 7

11121 Praha 1

Czech Republic http://www.cerge-ei.cz 